\title{
RFID as a Disruptive Innovation
}

\section{Vlad Krotov $^{1}$ and Iris Junglas ${ }^{2}$}

University of Houston, Bauer College of Business

${ }^{1}$ vokrotov@uh.edu, ${ }^{2}$ ijunglas@uh.edu

Received 26 July 2007; received in revised form 31 January 2008; accepted 14 April 2008

\begin{abstract}
The first part of the paper discusses Wal-Mart's adoption of RFID through the theoretical lens of the Resources, Processes, and Values (RPV) innovation theory. This part makes a theoretical argument that WalMart adopted RFID as a sustaining innovation - an incremental improvement in supply chain identification technology. The second part reviews a representative sample of IS literature in order to investigate whether IS researchers have been influenced by Wal-Mart's perspective on RFID. The literature review suggests that many IS researchers have also adopted Wal-Mart's perspective on RFID. The third part argues that RFID technology has a potential to become a disruptive technology with a profound impact on business and society. Given this possibility, both researchers and practitioners are provided with two frameworks ("object oriented approach" and "visionary approach") which can help them to adopt a more forward-looking perspective in relation to RFID. The object oriented approach starts from the basic capabilities offered by RFID technology and attempts to determine how these capabilities can be used to create a new RFID application. The visionary approach starts by assuming that RFID technology has reached its peak in terms of breadth of adoption and then tries to determine opportunities offered in this situation.
\end{abstract}

Key words: RFID, Future, Innovation, Resources, Processes, Values, Sustaining, Disruptive, New business models, New value propositions, Information superhighway 


\section{Introduction}

In June 2003 Wal-Mart mandated its top suppliers to use RFID tags on the pallet level [48]. Wal-Mart adopted RFID in a way consistent with its business model of a discount retailer. Discount model commanded Wal-Mart to adopt RFID as an improvement over barcodes - the company's existing supply chain identification technology. RFID has the potential to save billions of dollars for Wal-Mart and other retailers through improvements in supply chain efficiency [5], [49], [54], [65]. Since Wal-Mart has been the major driving force behind the recent explosion in RFID adoption, many companies and researchers have adopted Wal-Mart's perspective on the technology.

Improving supply chain efficiency of retailers and other "logistics intensive" organizations [71] may only be a shortterm impact of RFID. Many experts believe that in the future RFID may have a more profound impact on business and society. For example, Paul Saffo, research director for the Institute for the Future, believes that we are standing at an early stage of a new media revolution [43]. Similarly, Accenture [1], a leading technology consultancy, believes that the intelligent interaction of RFID-enabled devices "is potentially as revolutionary as the Internet and World Wide Web".

Although there is a growing realization of the potential of RFID, there is no guarantee that RFID will actually leave the supply chain identification domain. Predicting future can be a daunting task, especially in the turbulent domain of information technology. Therefore, this paper is not an attempt to predict the future of RIFD. Similarly to [39], this paper rather attempts to look "at past and present trends and use these trends for providing a road map of future possibilities" [p. 41]. Being aware of this possible future can help both researchers and practitioners to anticipate possible opportunities and threats associated with RFID.

This paper consists of three major parts. The first part discusses Wal-Mart's adoption of RFID through the theoretical lens of the Resources, Processes, and Values (RPV) theory. This part attempts to make a theoretical argument that Wal-Mart adopted RFID as a sustaining innovation - in line with the company's existing resources, processes, and values. Because of Wal-Mart's high bargaining power over its suppliers [45], Wal-Mart was able to push RFID adoption onto the suppliers. Moreover, Wal-Mart passed its vision in relation to RFID (with RFID being envisioned as a more efficient and effective replacement for barcodes) to the public. The second part reviews a representative sample of IS literature in order to investigate whether IS researchers have been influenced by Wal-Mart's perspective on RFID. The literature review suggests that many IS researchers have also adopted Wal-Mart's perspective on RFID, that is RFID is often viewed by researchers, either explicitly or implicitly, as an incremental improvement in supply chain identification. The third part makes a theoretical argument that RFID technology has a potential to become a disruptive technology with a profound impact outside of the supply chain identification domain. Given this possibility, both researchers and practitioners are provided with some guidelines which can help them anticipate the potentially disruptive impact of RFID technology and direct their efforts towards taking RFID technology beyond its mainstream application.

\section{Wal-Mart's Announcement}

RFID technology as it is today is a result of decades of theoretical research, field experiments, and pioneering commercialization attempts [2]. The "modern history" of RFID began in June 2003, when Wal-Mart's CIO Linda Dillman announced at a Retail Systems conference that Wal-Mart will mandate its top suppliers to start placing RFID tags with an EPC code on pallets and cases by January 1, 2005 [48]. A few months later, the Department of Defense (DoD) followed suit by releasing a similar mandate to its suppliers [12].

The 2003 announcements by Wal-Mart and DoD introduced RFID technology to the general public. After the announcements, a number of companies (predominantly retailers) began experimenting with RFID in their supply chains. The announcements also triggered publication of the first (mainly descriptive) papers on RFID in some of the most popular Information Systems (IS) outlets such as Communications of the ACM (e.g. [35]), Communications of the AIS (e.g. [5]), and MIS Quarterly Executive (e.g. [30]).

Both Wal-Mart and DoD cited improvement in supply chain efficiency and resulting cost reduction as the main reasons behind their decision to adopt RFID [5]. While answering questions at the 2003 Retail Systems conference, Wal-Mart's CIO Linda Dillman said [48]:

[RFID] will become a requirement, like EDI, because if we can't track your product with [EPC tags], it's an added cost for us that we have to pass on to our customers

Similarly, the DoD stated that better supply chain visibility achieved with RFID can help them to cut down costs associated with lost supplies [5]. 


\section{Conceptual Framework}

\subsection{Resources, Processes, and Values (RPV) Theory}

The desire to cut costs is an idiosyncratic explanation of why Wal-Mart decided to adopt RFID. The Resources, Processes, and Values (RPV) theory proposed by [16] offers a nomothetic explanation of why big companies like Wal-Mart either succeed or fail to adopt an innovation. According to RVP, "resources (what a firm has), processes (how a firm does its work), and values (what a firm wants to do) collectively define an organization's strengths as well as its weaknesses and blind spots" in relation to an emerging technology [16] pp. xvii,xviii.

Table 1: Definitions and Examples of Resources, Processes, and Values (Reprinted from [16])

\begin{tabular}{|l|l|l|}
\hline \multicolumn{1}{|c|}{ Resources } & \multicolumn{1}{|c|}{ Processes } & \multicolumn{1}{c|}{ Values } \\
\hline Things or assets that & Established ways companies turn & The criteria by which \\
organizations can buy, sell, \\
build or destroy. & resources into products or & prioritization decisions \\
Examples: & are made. \\
- People & Examples: & Examples: \\
- Technology & - Hiring and training & - Cost structure \\
- Products & - Product development & - Income statement \\
- Equipment & - Manufacturing & - Customer demands \\
- Information & - Planning and budgeting & - Size of opportunity \\
- Cash & - Market research & - Ethics \\
- Brand & - Resource allocation & \\
- Distribution channels & & \\
\hline
\end{tabular}

The theory posits that [16] pp. xvii,xviii:

...organizations successfully tackle opportunities when they have the resources to succeed, when their processes facilitate what needs to get done, and when their values allow them to give adequate priority to that particular opportunity in the face of all other demands that compete for the company's resources

As an example, [16] use RVP to explain why Western Union, a giant telegraph company, failed to adopt the telephone. Alexander Graham Bell offered his telephone invention patents to Western Union for a mere $\$ 100,000$ (which is equivalent to roughly $\$ 1.7$ million in today's dollars). Western Union turned down this offer. William Orton, Western Union's president, summarized the company's attitude towards the telephone in the following manner: "What use could this company make of an electrical toy?"

According to [16], Western Union's failure to embrace the telephone was not due to bad management. The failure can largely be attributed to the fact that the firm's resources, processes, and values could not accommodate the telephone. When Western Union was introduced to the telephone, their core business, long-distance telegraphy, seemed to be a better area for investment. Telegraphy is what had made the company so great over the years. Not surprisingly, all of the firm's resources and processes were tailored to the provision of the telegraphy service. The firm's customers at that time (railroads, newspapers, and financial brokerage houses) still needed better longdistance telegraphy service. Consequently, the company's decision to invest in existing resources and processes that supported its core business were not only in accordance with the company's values but also rational from an economic point of view.

\subsection{How and Why Wal-Mart Adopted RFID}

An implication of the RVP theory is that a company's decision to embrace a new opportunity may not necessarily be a result of good management [16]. A company embraces an innovation if it can be accommodated by the company's processes, resources and values.

Since Wal-Mart was able to embrace the new opportunity resulting from RFID, it can be argued that Wal-Mart's resources, processes, and values allowed for the successful adoption of the new technology. Wal-Mart is a giant retailer with annual sales of 345 billion and net income of 12 billion [66]. Therefore, it is safe to assume that Wal-Mart had adequate financial resources to invest in RFID. Bargaining power over suppliers [45] is another resource that helped to launch the initiative. Finally, Wal-Mart had existing supply chain identification infrastructure based on barcode technology, which had been rapidly adopted by the company in 1980's [49]. Adoption of RFID did not require radical modification of Wal-Mart's existing supply chain processes. Rather, it was a transition from barcodes to RFID. Finally, "always low prices" have been have been the major value behind Wal-Mart's decisions. It was estimated that replacing barcodes with RFID can help Wal-Mart to save more than 8 billion annually through reduced labor costs, out-of-stock expenses, theft, warehouse management costs, and inventory levels [5], [48]. RFID 
technology provided opportunities consistent with Wal-Mart's core value - "always low prices". Thus, Wal-Mart adopted RFID in a way which is consistent with its resources, processes, and values.

In addition to that, RPV [16] argues that large, established companies are likely to adopt sustaining innovations. A sustaining innovation is an incremental improvement of existing products or processes on the dimensions traditionally valued by customers [16]. Low prices are traditionally valued by Wal-Mart's customers. Since RFID has the potential to reduce costs, it is not surprising that Wal-Mart adopted RFID as efficiency and cost reduction innovation, which is a sustaining innovation for Wal-Mart.

\subsection{How Other Companies View RFID}

Because Wal-Mart has been a major driving force behind RFID adoption, other companies began looking at RFID through the lens of Wal-Mart's resources, processes, and values. A report by Gartner, summarizing the prevailing wisdom towards the value of RFID, says that the technology can be useful in the following situations [69]:

1. Processes where it is not feasible to use barcodes. Since barcodes lack durability, they cannot be used on objects undergoing rough handling (e.g., rail cars)

2. Processes requiring fast identification and counting. RFID may be a more efficient way for identifying or counting objects. Powerful RFID readers can automatically scan hundreds of items in a matter of a few seconds. In the case of barcodes, each items has to be scanned by an employee individually, which takes time

3. Interorganizational processes. A small supplier of a large retailer may not be motivated to maintain a strict and accurate account of its operations. The large retailer, on the other hand, may need this information to improve its supply chain efficiency. With the help of RFID, the process of acquiring this information can be automated, minimizing the chance of the supplier's lack of motivation interfering with the accuracy of this information

4. Chaotic processes. In order for a warehouse employee to scan the barcode of each individual item in a warehouse, the goods in the warehouse must be kept in certain order. In the case of RFID, order is not important. Theoretically, an inventory count may be taken effectively even if items are located chaotically.

5. Processes where exact configuration of goods must be maintained. Some RFID tags can transmit information omni directionally and some types of waves can pass through certain substances. Because of these features, a product consisting of several RFID-tagged parts can be inspected without disassembling the product.

6. Processes requiring secure identification. Through the user of encryption, the transmission of identification data from an RFID tag to a reader can be secured from eavesdropping.

7. Supercritical processes. RFID can prevent human error in critical processes. For example, RFID tags can be used to ensure that an intravenous (IV) pump starts pumping blood to a patient only when it "sees" the correct bag of blood attached to the pump.

This list conveys the idea that RFID can be used either to improve existing identification processes or to identify objects in situations where barcodes cannot be used. Thus, RFID is largely presented as a sustaining innovation an incremental improvement identification technology.

\section{Methodology}

The study uses literature review approach proposed by [68]. [68] suggest that the goal of a literature review is to facilitate theory development by summarizing current knowledge on a topic, identifying gaps in the current knowledge, and suggesting future research that can close to identify the gaps. In this respect, the approach undertaken here is different - this study uses literature review to make the argument that many is papers have adopted Wal-Mart's perspective on RFID, that is RFID is often viewed, either implicitly or explicitly, as a sustaining innovation.

\subsection{Identifying the Relevant Literature}

This study does not intend to provide a comprehensive, cross-disciplinary review of RFID literature. According to [68], a literature review on an emerging issue can less encompassing in terms of the scope and number of included articles. The intention of this study is to analyze a representative sample of RFID articles found in mainstream IS 
outlets. Therefore, the analysis of journal articles was limited to the following top ten journals, as listed by the Association of Information Systems [6]:

1. Management Information Systems Quarterly

2. Information Systems Research

3. Communications of the $\mathrm{ACM}$

4. Management Science

5. Journal of MIS

6. Artificial Intelligence

7. Decision Sciences

8. Harvard Business Review

9. IEEE Transactions (various)

10. Al Magazine

The journals listed above were searched for articles with the keyword "RFID" in the Business Source Complete database of the EBSCOhost search service. Even though IEEE Transactions (various) had 26 articles on RFID, they were excluded from analysis because all of them dealt with RFID-related engineering issues (e.g. RFID reader antenna design, RFID tag design, etc.).

While excluding IEEE Transactions (various) from the analysis, two additional IS journals were included:

1. Communications of $\mathrm{ACM}$

2. Communications of AIS

3. MISQ Executive

CACM was included due to the fact that this journal is often considered to be a top IS journal (see [6]), its concentration of emerging issues and technology, and the author's awareness of the special issue on RFID published in the journal. CAIS was included due to the authors' awareness of the journal's tendency to publish tutorials and opinion pieces on emerging issues and technologies. MISQ Executive was added due to the author's awareness of some early case studies on RFID adoption by European retailers published in the journal.

Recognizing the fact that RFID is an emerging technology, the analysis also included papers published in mainstream IS conferences, which are listed in the AIS electronic library [7]. Namely, proceedings of the following conferences were searched for using articles with the keyword "RFID" in the title.

1. ACIS

2. AMCIS

3. BLED

4. ECIS

5. ICIS

6. IRWITPM

7. MCIS

8. MWAIS

9. PACIS 
The journals and conference proceedings were searched in January, 2008. Table lists the number of articles identified in the journals and conference proceedings

Table 2: Articles Identified

\begin{tabular}{|c|c|}
\hline Outlet & Number \\
\hline AMCIS & 17 \\
\hline CACM & 10 \\
\hline CAIS & 5 \\
\hline Decision Sciences & 1 \\
\hline ECIS & 1 \\
\hline ICIS & 1 \\
\hline MISQ Executive & 3 \\
\hline PACIS & 1 \\
\hline Total: & 39 \\
\hline
\end{tabular}

\subsection{Analysis}

This paper uses the "concept-centric" approach to literature review proposed by [68]. First, each of the articles listed in Appendix I was read and its major theme was captured with 1-2 sentences. The results of the first round of reviewing the literature were tabulated using the table (or "concept matrix") found in Appendix I. Secondly, the themes of each of the article were revisited to identify the primary focus of the article with respect to RFID technology. The goal of this last step was to determine whether an article views RFID as a supply chain identification technology or attempts to look at the potential of RFID outside of the supply chain.

\section{Findings}

A review of papers on RFID published in traditional Information Systems (IS) outlets (see Appendix I and Table 3) reveals that most IS researchers largely adopted Wal-Mart's perspective on RFID. Most papers reviewed (25 out of 39) view RFID a sustaining innovation - a more effective replacement of barcode technology in supply chain identification. Some of the earlier RFID papers (3 out of 39) ([5], [10], [53]) are essentially RFID tutorials with overview of the technology and discussion of technical and managerial issues associated with RFID adoption in supply chain. The category also includes empirical case studies on RFID implementations carried out by predominantly European retailers (e.g. [31] - [35]). The main focus of these case studies is success factors behind RFID implementations. Several articles (e.g. [46], [57]) use different theoretical perspectives to identify antecedents of the intention to adopt RFID by retailers and their suppliers. Finally, some articles (e.g. [13]) propose technical solutions for improving efficiency of RFID systems in retail. This research is of direct relevance to Wal-Mart and other companies interested in improving their supply chain efficiency with the help of RFID.

Table 3: Major Focus of IS Publications on RFID

\begin{tabular}{|c|c|}
\hline Major Focus & Number of Articles \\
\hline Supply Chain & 25 \\
\hline Privacy/Security & 9 \\
\hline Future Applications & 5 \\
\hline
\end{tabular}

9 articles deal with privacy and security issues related to RFID (most articles view the security/privacy issues in the supply chain domain). Katherine Albrecht, the head of the Consumers against Supermarket Privacy Invasion and Numbering (CASPIAN) privacy group (the first privacy group to address privacy controversy surrounding RFID), identified 5 ways in which RFID can threaten privacy and civil liberties [3]:

\section{Hidden placement of tags}

2. Unique identifiers for all objects worldwide

3. Massive data aggregation

\section{Hidden readers}

\section{Individual tracking and profiling}

Virtually all of the articles in this category elaborate on these five privacy threats and propose technical as well as managerial solutions for dealing with the privacy threats. Again, privacy has been one of the central problems for 
Wal-Mart and other retailers. The scandal involving field trials of RFID technology by Wal-Mart and Gillette was one of the first public controversies surrounding RFID usage in retail [3]. Successfully addressing privacy concerns is certainly important to Wal-Mart and other retailers.

Only a small group of papers (5 out of 39) focuses on RFID applications outside of the supply chain. For example [56] identify issues and values that are of concern to customers of Silent Commerce - commerce based on transactions executed with the help of RFID and other sensor technologies. [4] discuss the possibility of using RFID tags to track banknotes. [59] propose using bracelets with an embedded RFID tag to detect human activity. While of no direct relevance to Wal-Mart, many of the articles in this category are primarily concerned with the question of how RFID can be used to track items in the supply chain and what problems need to be solved in relation to RFID tracking. This theme is also parallel to what Wal-Mart is doing with RFID today.

There is nothing wrong with viewing RFID as a new supply chain identification technology. RFID technology has the potential to increase supply chain efficiency in a variety of supply chain scenarios and save billions to Wal-Mart and other retailers [5], [49]. Because RFID is still an emerging technology with many pending issues, researchers have to address a number of technical, managerial, and privacy issues in order for these cost reductions to fully materialize [18], [29]. Therefore, researchers are completely rational in pursuing the currently predominant research direction in relation to RFID, which is summarized in Table 1. However, one should not forget that "as a society, we typically overestimate the short-term impact of new technologies and underestimate their long-term impact" [53] p. 301. Viewing RFID as an improvement in supply chain identification may be only short-term perspective on the potential of RFID.

\title{
6 RFID as a Disruptive Innovation
}

\subsection{The Long-Term Potential of RFID}

The long-term impact of RFID may go well beyond improving supply chain efficiency. An analogy to the Internet can be drawn here. The Internet was initially perceived as a technology allowing computers to "talk" to each other. However, the exchange of data among computers was only a short-term impact of the Internet. Robert Taylor, an Internet pioneer and former Xerox PARC manager, reported that his vision of the Internet was rejected at Bell Labs and IBM by researchers who said "our computers already talk to each other" [8]. Thus, researchers at Bell Labs and IBM rejected the Internet on the grounds of a short-term vision.

In the long run, this capability brought us closer to the emergence of "information superhighway" - a global and ubiquitous network of computers and electronic devices transmitting large volumes of information at a high speed [20]. The long-term impact of the Internet involved changing the way people live and work. If managers at Bell Labs and IBM had this long-term impact of the Internet in mind, would they reject Robert Taylor's idea? A long-term perspective on the Internet would probably make them pay closer attention to the technology and, as a result, make better long-term decisions in relation to the Internet.

In the long-term, RFID may have the potential to take the concept of the information superhighway to a level previously unimaginable by the technology visionaries of the late $20^{\text {th }}$ century. With the help of RFID, virtually any physical object can become connected the "information superhighway" and communicate with other physical objects, animals [64] or humans [37]. Auto-ID Labs, a federation of research universities founded in 1999, has the following vision on the future development of RFID [50]:

\begin{abstract}
... a world in which all electronic devices are networked and every object, whether it is physical or electronic, is electronically tagged with information pertinent to that object. We envision the use of physical tags that allow remote, contactless interrogation of their contents; thus, enabling all physical objects to act as nodes in a networked physical world.
\end{abstract}

Paul Saffo, research director for the Institute for the Future, relieves that this "Internet of Things" envisioned by AutoID can become a platform for a new media revolution [43]. With the help of RFID, virtually any physical object can become a part of the "information superhighway" and communicate with other physical objects, animals, or humans. RFID can turn lifeless objects into "smartifacts" - intelligent devices capable of "observing the world on our behalf and increasingly manipulating it on our behalf" [43]. Accenture [1] believes that the intelligent interaction of smartifacts "is potentially as revolutionary as the Internet and World Wide Web".

\subsection{Evidence of RFID Having the Potential to Become a Disruptive Innovation}

With this perspective in mind, it is important to determine the likely path of RFID evolvement as well as its potential long-term impact. It is possible that RFID, just like the Internet, will take the path of a disruptive innovation. According to [16]: 
Disruptive innovations introduce a new value proposition. They either create new markets or reshape existing markets (p. xvii)

Disruptive innovations are likely to come from companies outside of the retail industry. RPV theory posits that new value propositions are not likely to come from well-established companies. Resources, processes, and values of big retailers like Wal-Mart may be incapable of embracing a new business opportunity. Paul Saffo supported this idea by delivering the following message to the early adopters of RFID technology [43]:

Your business is just at the point where you could bury yourself in RFID issues and that would be a horrible mistake, because you'll miss the big opportunities... The biggest impact on your business is going to come from things utterly outside of it. So pay attention to the things on the outside.

Indeed, several companies outside of the retail industry have already used RFID to create new value propositions:

- Accenture's "Virtual Showroom" prototype consists of RFID tags embedded into consumer products and a PDA with a built-in RFID reader. Consumers can use the PDA to get information on products they see in real world and purchase them "on the spot". For example, Mr. Smith may see a shirt that he likes on one of his co-workers. Since the shirt has an embedded RFID tag with a unique identification number, Mr. Smith can use a PDA with wireless capabilities to pull out information about this shirt from an online database and place an order immediately.

- $\quad$ Cafes and stores in Seattle are using RFID technology for marketing products and services [11]. At the core of this new advertisement system are the so-called "activation fields" (areas covered by the field of an RFID reader) and active RFID tags that are carried by customers of this system. Whenever a customer enters an activation field, loud speakers which are usually mounted on a telephone booth broadcast a commercial message. The system can also display a video message on a monitor with commercial information for cafes or local retailers. One of the primary target audiences for this new system are visually and hearing impaired individuals.

- $\quad$ Exploratorium, a science museum in San Francisco, uses an RFID-based system called eXport for enhancing customer experience [24]. At the museum's entrance, each customer receives an RFID tag in the form of a necklace. When a customer interacts with a particular exhibition stand (e.g. sprays water onto a refrigerated glass to form and explore ice crystals), the customer's RFID tag triggers digital cameras which take pictures of the customer and the ice crystals that he or she has created. These pictures are uploaded to a customized web site together with the related text information. The web site can be viewed by the customer in his or her spare time.

- Négone, a Madrid-based developer of interactive games, opened a game named "La Fuga" (The Breakout) at the premises of a former bank in Madrid [17]. The game stimulates experiences of an inmate escaping a high-security prison. Each person wishing to participate in this game is supplied with a Personal Digital Assistant (PDA) and an RFID tag. RFID readers are placed in doorways and other areas in the former bank's premises. The game system is able to identify players and enhance their gaming experience. By detecting the players' RFID tags, the system can display questions on the players' PDA and open doors for them.

Of course, these RFID applications rely on wireless, automatic identification. However, these applications are not about mere identification. At the core of these applications is the idea that objects (advertisement displays or exhibition stands) can seamlessly interact with humans, creating new types of services for the customer.

\section{Suggestions for a Forward-Looking Perspective}

Given that it is possible that RFID can have a revolutionary impact, both IS practitioners and researchers need to become more forward looking in relation to RFID. Being forward-looking and relevant in RFID research is not a matter of rigor, methodology, theoretical stance, or subject matter. It is an approach where RFID-related issues are addressed with the possible future applications of RFID in mind. This paper proposed two ways for thinking about the future of RFID: "object oriented approach" and "visionary approach" [29]. The object oriented approach is a "bottomup" approach - it starts from the basic capabilities offered by RFID technology and attempts to determine how these capabilities can be used to create a new RFID application. The core capability of RFID, as defined in this article, is the ability to automatically and wirelessly identify an object together with its properties. The visionary approach is a "top-down" approach - it starts by assuming that RFID technology has reached its peak in terms of breadth of adoption and then tries to determine opportunities offered in this situation. 


\subsection{Object-Oriented Approach}

The object-oriented approach draws on the object-oriented programming paradigm to organize thinking towards the future of RFID. The approach requires looking at an object (a human, animal, or physical item) in terms of its properties and methods. Properties, in this case, are characteristics of an object which are relevant for a particular transaction. A method is what an object "can do," that is the transactions it may participate in. For example, a box of microwavable food is an object with a property of cooking time. The microwavable food participates in the transaction of being cooked in a microwave.

This type of analysis proceeds as follows (Figure 1). First, select an object. Then think about properties that the object may have. Next, determine how RFID can help to extract and use these properties either to enhance a transaction that the object participates in or to create a new transaction. Hence, new value propositions can be built either by improving existing transactions or creating new ones.

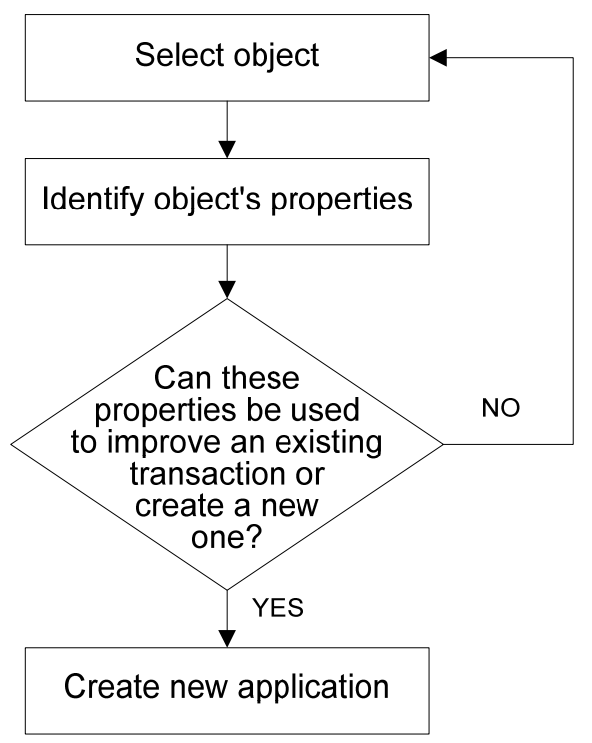

Figure 1: How to Create Innovative RFID applications

For example, a box of microwavable food has a property of cooking time. The food participates in the transaction of being cooked in a microwave. Given that the microwave is equipped with an RFID reader, the box can automatically communicate its cooking time to the microwave. In this case, RFID is improves an existing transaction (cooking) by eliminating the need to search for cooking time on the box and then manually entering the time using the microwave's console. RFID can also help to create a new transaction between the microwavable dinner and a refrigerator using another property of the microwavable dinner - the expiration date. Given that the refrigerator is equipped with an RFID reader, the refrigerator can detect when the dinner has expired and display an expiration notice to its owner. Moreover, the refrigerator can add a box of microwavable dinner to an electronic shopping list so that dinner supplies can be replenished next time the owner goes to a store.

\subsection{Visionary Approach}

Another way to start thinking about the future of RFID is to start with a vision of broad adoption of RFID. Imagine a world where each individual, animal, and physical object has an RFID tag. Imagine a ubiquitous wireless network that can identify the location and retrieve properties of every individual, animal, or human object. With this vision in mind, answer the following questions:

- What new forms of knowledge can this data produce?

- What improvements to existing business models can be made by utilizing this knowledge?

- Which new business models can be created with this newly available knowledge?

For example, imagine a "smart" refrigerator which is a node of the "Internet of Things". With this capability, the refrigerator may not only detect the expiration of items inside, but also help the owner to do grocery shopping. Given the owner's diet, budget preferences, and physical location, the refrigerator will be able to create an optimal 
shopping list by taking into account price, nutritional characteristics, and physical proximity of the needed food items. The refrigerator can even automatically place an order online, eliminating the chore of grocery shopping.

Here's another example of going from a vision to business opportunities in relation to RFID. Imagine every car being a node of a global, pervasive network. Then, a city government could identify and track movement of cars through its freeway system. This information can be used to impose road improvement taxes on vehicle owners proportional to the actual usage of the freeway system. Similarly, an advertising agency may use this information to position billboards along the freeway. Opportunities can be endless if this vision becomes a reality.

\section{Conclusion}

Given that it is possible that RFID can have a revolutionary impact, both IS practitioners and researchers need to adopt a more forward looking stance in relation to RFID. Viewing RFID as an incremental improvement in supply chain identification can result in serious consequences for practitioners and researchers alike. In the case of practitioners, RFID can turn out to be a disruptive innovation, capable of destroying existing competencies [52]. Failure to embrace the new challenges and opportunities may end the existence of a company, just like failure to embrace the telephone lead to the death of Western Union. Successful adoption of a disruptive innovation, on the other hand, may help a company to identify new sources of growth [15]. In the case of researchers, failure to become more forward-looking in relation to RFID may result in a situation where researchers merely follow the world of practice, reinventing the "buzz words" invented by consultants and seeking theoretical justification for something which is already common knowledge in the world of practice. IS research is often criticized for lagging behind the practitioner's world and failing to address the needs of practitioners. Concentrating on the future of RFID can help researchers to produce knowledge that moves the society towards the current vision of "information superhighway".

\section{References}

[1] Accenture (2002, July), Seize the day: The silent commerce imperative. [Online]. Available: http://www.accen ture.com/NR/rdonlyres/1E69F408-F4D7-40E8-952F-DAC9E60A0EA3/0/SeizeTheDay.pdf.

[2] AIM, Inc. (2001, October), The shrouds of time: The history of RFID [Online]. Available: http://www.rfid consultation.eu/docs/ficheiros/shrouds of time.pdf.

[3] K. Albrecht (2003, November), RFID: Privacy and societal implications, RFID Privacy Workshop, MIT Media Lab [Online]. Available: http://www.media.mit.edu/events/movies/video.php?id=rfidprivacy-2003-11-15-1.

[4] I. Angell and J. Kietzmannm, RFID and the end of cash?, Communications of the ACM, vol. 49, no. 12, December 2006, pp. 91-96.

[5] Z. Asif and M. Mandviwalla, Integrating the supply chain with RFID: A technical and business analysis, Communications of the AIS, vol. 15, no. 24, March 2005, pp. 393-426.

[6] Association for Information Systems (2008, January), MIS journal rankings [Online]. Available: http://www.is world.org/csaunders/rankings.htm.

[7] Association for Information Systems (2008, January), AIS electronic library [Online]. Available: http://aisel.is world.orgl.

[8] R. D. Austin and R. L. Nolan, In search of the next "killer application", MIT Sloan Management Review, vol. 46, no. 4, June 2005, pp. 96-96.

[9] E. Bendoly, A. Citurs, and B. Konsynski, Internal infrastructural impacts on RFID percpetions and commitment: knowledge, operational procedures, and information-processing standards, Decision Sciences, vol. 38, no. 3, August 2007, pp. 423-449.

[10] G. Boriello, RFID: Tagging the world, Communications of the ACM, vol. 48, no. 9, September 2005, pp. 34-37.

[11] J. Bostrom (2005, May) Marketing via RFID comes to Seattle, Computerworld [Online]. Available: http://com puterworld.com/mobiletopics/mobile/technology/story/0,10801,101951,00.html.

[12] B. Brewin (2003, October), Defense Dept. orders its suppliers to use RFID tags by 2005, Computerworld [Online]. Available: http://www.computerworld.com/softwaretopics/erp/story/0,10801,85869,00.html.

[13] S. Chalasani and J. Sounderpandian, RFID for retail store information systems, in Proceedings of the $10^{\text {th }}$ Americas Conference on Information Systems, New York, New York, August 2004, pp. 3845-3955.

[14] S. Chalasani, R. Boppana, and J. Sounderpandian, RFID tag reader designs for retail store applications, in Proceedings of the $11^{\text {th }}$ Americas Conference on Information Systems, Omaha, Nebraska, August 2005, pp. 2219-2228.

[15] C.M. Christensen and M.E. Raynor, The innovator's solution: Creating and sustaining successful growth, Harvard Business School Press: Boston, Massachusetts, 2003.

[16] C.M. Christensen, A.D. Anthony and E.A. Roth, Seeing What's Next, Harvard Business School Press: Boston, Massachusetts, 2004.

[17] J. Collins (2005, November), RFID Helps gamers break out of jail, RFID Journal [Online]. Available: http:// www.rfidjournal.com/article/articleprint/1986/-1/1.

[18] T.Coltman, R. Gadh and K. Michaels, RFID and supply chain management: Introduction to the special issue, Journal of Theoretical and Applied Electronic Commerce Research, vol. 3, no 1, April 2008, pp. iii-vi. 
[19] J. Fedorowicz, J. L. Gogan, and C. Williams, RFID and interorganizational collaboration: political and administrative challenges, in proceedings of the 13th Americas Conference on Information Systems 2007, Keystone, Collorado, August 2007.

[20] B. Gates, The Road Ahead, Penguin Books: New York, New York, 1995.

[21] P. Golding and V. Tennant, Performance metrics: Evaluating radio frequency identification (RFID) library system, in proceedings of the International Conference on Information Systems ICIS 2007 Montréal, Québec, Canada, December 2007.

[22] O. Gunther, and S. Spieakerman, RFID and the perception of control: The consumer's view, Communications of the ACM, vol. 48, no. 9, September 2005, pp. 73-76

[23] B.C. Hardgrave, M. Waller and R. Miller (2006, June), RFID's impact on out of stocks: a sales velocity analysis, RFID Research Center, University of Arkansas [Online]. Available: http://itri.uark.edu/research/display.asp? article=ITRI-WP068-0606.

[24] S. Hsi and H. Fait, RFID enhances visitors' museum experience at the Exploratorium, Communications of the ACM, vol. 48, no. 9, September 2005, pp. 60-65.

[25] N. Huber and K. Michael, vendor perceptions of how RFID can minimize product shrinkage in the retail supply chain, IEEE RFID Eurasia, Istanbul, Turkey, September 2007, pp. 1-6.

[26] B.D. Janz, M.G. Pitts and R.F. Otondo, Information systems and health care XX: Back to the future with RFID: Lessons learned - some old, some new, Communications of the AIS, vol. 15, January 2005, pp. 132-147.

[27] A. S. Jensen, J. Cazier and D. Dinesh, The impact of government trust perception on privacy risk perceptions and consumer acceptance of residual RFID technologies, in proceedings of the 13th Americas Conference on Information Systems 2007, Keystone, Collorado, August 2007.

[28] U. Knebel, J.M. Leimeister and H. Krcmar, Strategic importance of RFID - the CIO perspective: An empirical analysis in Germany, in Proceedings of the $12^{\text {th }}$ Americas Conference on Information Systems, Acapulco, Mexico, August 2006, pp. 1991-2002.

[29] V. Krotov, RFID (2008, January), Thinking outside of the supply chain, CIO Magazine [Online]. Available: http:// cio.com/article/174108/.

[30] C. Loebecke, Modernizing retailing worldwide at the point of sale, MIS Quarterly Executive, vol. 3, no. 4, December 2004, pp. 177-187.

[31] C. Loebbecke, Emerging information system applications in brick-and-mortar supermarkets: A case study of content provision devices and RFID-based implementations, in Proceedings of the $9^{\text {th }}$ Pacific Asia Conference on Information Systems, Bangkok, Thailand, July 2005.

[32] C. Loebbecke and C. Huyskens, Weaving the RFID yarn at the fashion industry: The Kaufhof case, MIS Quarterly Executive, vol. 5, no. 4, June 2006, pp. 169-179.

[33] C. Loebbecke and J. Palmer, RFID becomes fashionable in the supply chain: the case of Kaufhof and Gerry Weber, Proceedings of the $12^{\text {th }}$ Americas Conference on Information Systems, Acapulco, Mexico, August 2006, pp. 1887-1894.

[34] C. Loebbecke and J. Palmer, RFID in the fashion industry: Kaufhof department stores AG and Gerry Weber International AG, Fashion Manufacturer, MIS Quarterly Executive, vol. 5, no. 2, June 2006, pp. 69-79.

[35] C. Loebbecke, M. Fujita, C. Huyskens, Towards item-level RFID in the Japanese publishing industry, in proceedings of the 13th Americas Conference on Information Systems 2007, Keystone, Collorado, August 2007.

[36] J. Lowe, Bill Gates Speaks, John Wiley and Sons: New York, New York, 1998.

[37] A. Masters and K. Michael, humancentric applications of RFID implants: The usability contexts of control, convenience, and care, in proceedings of the Second IEEE International Workshop on Mobile Commerce and Services, 19 July 2005 , pp. $32-41$.

[38] M. McGrinity, RFID: is this game of tag fair play?, Communications of the ACM, vol. 47, no. 1, January 2004, pp. 15-18.

[39] K. Michael (2003), The technological trajectory of the automatic identification industry, University of Wollongong, Australia, Doctoral Thesis, [Online]. Available: http://www.library.uow.edu.au/adt-NWU/public/adt-NWU200407 26.1424471.

[40] K. Michael and L. McCathie, The pros and cons of RFID in supply chain management, in Proceedings of the International Conference on Mobile Business, [Online]. Available: http://ro.uow.edu.au/cgi/viewcontent.cgi?arti cle $=1104 \&$ context=infopapers.

[41] P.G. Neumann and L. Weinstein, Risks of RFID, Communications of the ACM, vol. 49, no. 5, May 2006, p. 136

[42] F. Niederman, R.G. Mathieu, R. Morley, and I.-W. Kwon, Examining RFID application in supply chain management, Communications of the ACM, vol. 50, issue 7, July 2007, pp. 93-101.

[43] M.C. O'Connor (2005, April), RFID and the media revolution, RFID Journal [Online]. Available: http://www.rfid journal.com/article/articleview/1508/1/1/.

[44] M. Ohkubo, K. Suzuki and S. Kinoshita, RFID privacy issues and technical challenges, Communications of the ACM, vol. 48, no. 9, September 2005, pp. 66-71.

[45] M.E. Porter, Competitive strategy, The Free Press, New York, 1980.

[46] C. Ranganathan and S. Jha, adoption of RFID technology: An exploratory examination from supplier's perspective, in Proceedings of the 11th Americas Conference on Information Systems, Omaha, Nebraska, August 2005, pp. 2199-2199.

[47] C. Riemenschneider, B. Hardgrave, and D. Armstrong, Is there a business case for RFID?, in proceedings of the 13th Americas Conference on Information Systems 2007, Keystone, Collorado, August 2007.

[48] RFID Journal (2003, June), Wal-Mart draws line in the sand [Online]. Available: http://www.rfid journal.com/article/view/462/1/1/. 
[49] M. Roberti (2003, September), Case study: Wal-Mart's race for RFID, eWeek [Online]. Available: http://www.e week.com/article2/0,1895,1492297,00.asp.

[50] S. Sarma, D.L. Brock and K. Ashton (2000, October), The networked physical world, Auto-ID Center [Online]. Available: http://autoid.mit.edu/whitepapers/MIT-AUTOID-WH-001.PDF.

[51] A. Sengupta and V. Sethi, AMCIS 2007 panel summary: The promise of RFID technologies, Communications of the AIS, vol. 20, no. 56, December 2007.

[52] J.A. Schumpeter, Capitalism, socialism, and democracy, Harper: New York, 1942.

[53] H. Smith and B. Konsynski, Developments in practice X: Radio Frequency Identification (RFID) - an internet of physical objects, Communications of the AIS, vol. 12, no. 19, September 2003, pp. 301-310.

[54] C.-B. Soon and J.A. Guttierez, Effects of the RFID mandate on supply chain management, Journal of Theoretical and Applied Electronic Commerce Research, vol. 3, no 1, April 2008, pp. 81-91.

[55] S. Spiekerman and H. Ziekow, RFID: a 7-point plan to ensure privacy, in Proceedings of the 13th European Conference on Information Systems, Regensburg, Germany, May 2005.

[56] H. Sheng, F. Nah, and K. Siau, Values of silent commerce: A study using value-focused thinking approach, in Proceedings of the $11^{\text {th }}$ Americas Conference on Information Systems, Omaha, Nebraska, August 2005, pp. 1869-1881.

[57] A. Sharma and A. Citurs, Radio Frequency Identification (RFID) adoption drivers: A radical innovation adoption perspective, in Proceedings of the $11^{\text {th }}$ Americas Conference on Information Systems, Omaha, Nebraska, August 2005, pp. 1213-1218.

[58] J.P. Shim, U. Arshney and S. Dekleva, Wireless evolution 2006: Cellular TV, wearable computing, and RFID, Communications of the AIS, vol. 18, no. 24, November 2006, pp. 497-518.

[59] J.R. Smith, K.P. Fishkin, J. Bing, A. Hilipose, A. Rea, S. Roy and K. Sundara-Rajan, RFID-based techniques for human activity detection, Communications of the ACM, vol. 48, no. 9, September 2005, pp. 39-44.

[60] F. Stahl M. Freudenchuss, Mobile business through RFID technology: About the potential of RFID technology for distributing free and paid content on mobile devices in retail business, in proceedings of the $12^{\text {th }}$ Americas Conference on Information Systems, Acapulco, Mexico, August 2006, pp. 1931-1940.

[61] F. Stajano, RFID is x-ray vision, Communications of the ACM, vol. 48, no. 9, September 2005, pp. 31-33. M.S. Stanton, Consumer beliefs about Radio Frequency Identification (RFID) systems, in Proceedings of the $12^{\text {th }}$ Americas Conference on Information Systems, Acapulco, Mexico, August 2006, pp. 3346-3352.

[62] F. Thiesse, E. Fleisch, and C. Sorensen, RFID-enabled shelf replenishment with case-level tagging: A simulation study, in proceedings of the 13th Americas Conference on Information Systems 2007, Keystone, Collorado, August 2007.

[63] F. Thiesse, C. Floerkemeier, E. Fleisch, and C. Sorensen, Assessing the impact of privacy-enhancing technologies for RFID in the retail industry, in proceedings of the 13th Americas Conference on Information Systems 2007, Keystone, Collorado, August 2007.

[64] A. Trevarthen and K. Michael, Beyond mere compliance of RFID regultions by the farming community: A case study of the Cochrane Diary Farm, 6th International Conference on the Management of Mobile Business, 2007.

[65] D. Veeramani, J. Tang, and A. Guttierez, A Framework for Assessing the Value of RFID Implementation by TierOne Suppliers to Major Retailers, Journal of Theoretical and Applied Electronic Commerce Research, vol. 3, no 1, April 2008, pp. 55-70.

[66] Wal-Mart (2007), Annual Report [Online]. Available: http://walmartstores.com/Files/2007 annual report.pdf

[67] S.F. Wamba, Y. Bendavid, L.A. Lefebvre and E. Lefebvre, RFID and the EPC network as enablers of mobile business: A case study in the retail industry, in Proceedings of the $12^{\text {th }}$ Americas Conference on Information Systems, Acapulco, Mexico, August 2006, pp. 1949-1958.

[68] J. Webster and R. T. Watson, Analyzing the past to prepare for the future: Writing a literature review, MIS Quarterly, vol. 26, no. 2, June 2002, pp. xiii-xxiii.

[69] J. Woods, Heuristics for the Profitable Use of RFID, Gartner, Strategic Planning, June 2004, SPA-23-1479

[70] J. Yu, C. C. Lewis and C. Guo, RFID application in the food industry: A case study of Korean food safety information systems project, in proceedings of the 13th Americas Conference on Information Systems 2007, Keystone, Collorado, August 2007.

[71] T. Zhang, Y. Ouyang, and Y. He, Traceable Air Baggage Handling System Based on RFID Tags in the Airport Journal of Theoretical and Applied Electronic Commerce Research, vol. 3, no 1, April 2008, pp. 106-115. 


\section{Appendix}

Table 4: RFID Papers Published in IS Outlets

\begin{tabular}{|c|c|c|c|c|c|c|}
\hline & Author(s) & Year & Title & Outlet & Major Theme(s) & Focus \\
\hline 1 & Smith, Konsynski & 2003 & $\begin{array}{l}\text { Developments in } \\
\text { Practice X: Radio } \\
\text { Frequency } \\
\text { Identification } \\
\text { (RFID) - An } \\
\text { Internet of } \\
\text { Physical Objects }\end{array}$ & CAIS & $\begin{array}{l}\text { Provides overview of } \\
\text { RFID technology and } \\
\text { looks at several classes of } \\
\text { RFID applications }\end{array}$ & Supply Chain \\
\hline 2 & $\begin{array}{l}\text { Chalasani, } \\
\text { Sounderpandian }\end{array}$ & 2004 & $\begin{array}{l}\text { RFID for Retail } \\
\text { Store Information } \\
\text { Systems }\end{array}$ & AMCIS & $\begin{array}{l}\text { Proposes an analytical } \\
\text { approach to estimate } \\
\text { information processing } \\
\text { load rate on RFID-based } \\
\text { retail systems }\end{array}$ & Supply Chain \\
\hline 3 & McGrinity & 2004 & $\begin{array}{l}\text { RFID: Is This } \\
\text { Game of Tag Fair } \\
\text { Play? }\end{array}$ & CACM & $\begin{array}{l}\text { Argues that RFID brings } \\
\text { both consumer benefits as } \\
\text { well as Privacy/Security } \\
\text { threats }\end{array}$ & Privacy/Security \\
\hline 4 & Loebbecke & 2004 & $\begin{array}{l}\text { Modernizing } \\
\text { Retailing } \\
\text { Worldwide at the } \\
\text { Point of Sale }\end{array}$ & $\begin{array}{c}\text { MISQ } \\
\text { Executive }\end{array}$ & $\begin{array}{l}\text { Studies the Future Store } \\
\text { Initiative of Metro Group, a } \\
\text { large German retailer }\end{array}$ & Supply Chain \\
\hline 5 & $\begin{array}{l}\text { Asif, } \\
\text { Mandviwalla }\end{array}$ & 2005 & $\begin{array}{l}\text { Integrating the } \\
\text { Supply Chain with } \\
\text { RFID: A Technical } \\
\text { and Business } \\
\text { Analysis }\end{array}$ & CAIS & $\begin{array}{l}\text { Provides overview of } \\
\text { RFID technology together } \\
\text { with technical and } \\
\text { business implication of } \\
\text { using RFID in supply } \\
\text { chain }\end{array}$ & Supply Chain \\
\hline 6 & Sarah, Holger & 2005 & $\begin{array}{l}\text { RFID: A 7-Point } \\
\text { Plan to Ensure } \\
\text { Privacy/Security }\end{array}$ & ECIS & $\begin{array}{l}\text { Lists Privacy/Security and } \\
\text { security problems } \\
\text { resulting from RFID } \\
\text { adoption and lists } \\
\text { approaches which can be } \\
\text { used to address these } \\
\text { problems }\end{array}$ & Privacy/Security \\
\hline 7 & Loebbecke & 2005 & $\begin{array}{l}\text { Emerging } \\
\text { Information } \\
\text { System } \\
\text { Applications in } \\
\text { Brick-and- } \\
\text { Mortar } \\
\text { Supermarkets: } \\
\text { A Case Study of } \\
\text { Content } \\
\text { Provision } \\
\text { Devices and } \\
\text { RFID-Based } \\
\text { implementations }\end{array}$ & PACIS & $\begin{array}{l}\text { Covers Metro Group's } \\
\text { Future Store Initiative, } \\
\text { investigates organizational } \\
\text { impact of RFID } \\
\text { applications on brick-and- } \\
\text { mortar retailers }\end{array}$ & Supply Chain \\
\hline 8 & Sheng, Nah, Siau & 2005 & $\begin{array}{l}\text { Values of Silent } \\
\text { Commerce: A } \\
\text { Study Using } \\
\text { Value-Focused } \\
\text { Thinking } \\
\text { Approach }\end{array}$ & AMCIS & $\begin{array}{l}\text { Identifies issues and } \\
\text { values that are of concern } \\
\text { to customers of Silent } \\
\text { Commerce - commerce } \\
\text { based on transactions } \\
\text { executed with the help of } \\
\text { RFID and other sensor } \\
\text { technologies }\end{array}$ & $\begin{array}{c}\text { Future } \\
\text { Applications }\end{array}$ \\
\hline 9 & $\begin{array}{l}\text { Ranganathan, } \\
\text { Jha }\end{array}$ & 2005 & $\begin{array}{l}\text { Adoption of RFID } \\
\text { Technology: An }\end{array}$ & AMCIS & $\begin{array}{l}\text { Investigates antecedents } \\
\text { of a supplier's intention to }\end{array}$ & Supply Chain \\
\hline
\end{tabular}




\begin{tabular}{|c|c|c|c|c|c|c|}
\hline & & & $\begin{array}{l}\text { Exploratory } \\
\text { Examination from } \\
\text { Supplier's } \\
\text { Perspective }\end{array}$ & & adopt RFID & \\
\hline 10 & $\begin{array}{l}\text { Janz, Pitts, } \\
\text { Otondo }\end{array}$ & 2005 & $\begin{array}{l}\text { Information } \\
\text { Systems and } \\
\text { Health Care II: } \\
\text { Back to the Future } \\
\text { with RFID: } \\
\text { Lessons Learned } \\
\text { - Some Old, } \\
\text { Some New }\end{array}$ & CAIS & $\begin{array}{l}\text { Studies RFID } \\
\text { implementation at a } \\
\text { healthcare unit, } \\
\text { investigates challenges } \\
\text { and benefits related to the } \\
\text { implementation. }\end{array}$ & Supply Chain \\
\hline 11 & $\begin{array}{l}\text { Chalasani, } \\
\text { Boppana, } \\
\text { Sounderpandian }\end{array}$ & 2005 & $\begin{array}{l}\text { RFID Tag Reader } \\
\text { Designs for Retail } \\
\text { Store Applications }\end{array}$ & AMCIS & $\begin{array}{l}\text { Proposes technical } \\
\text { solutions designed to } \\
\text { improve operating } \\
\text { efficiency of RFID } \\
\text { systems }\end{array}$ & Supply Chain \\
\hline 12 & Stajano & 2005 & $\begin{array}{l}\text { RFID Is X-Ray } \\
\text { Vision }\end{array}$ & CACM & $\begin{array}{l}\text { Discusses security and } \\
\text { Privacy/Security issues } \\
\text { related to RFID }\end{array}$ & Privacy/Security \\
\hline 13 & Boriello & 2005 & $\begin{array}{l}\text { RFID: Tagging the } \\
\text { World }\end{array}$ & CACM & $\begin{array}{l}\text { Discusses how RFID can } \\
\text { be useful in classifying, } \\
\text { tagging, and organizing } \\
\text { objects }\end{array}$ & Supply Chain \\
\hline 14 & $\begin{array}{l}\text { Smith, Fishkin } \\
\text { Bing Jiang, } \\
\text { Mamishev, } \\
\text { Hilipose, Rea, } \\
\text { Sundara-Rajan, }\end{array}$ & 2005 & $\begin{array}{l}\text { RFID-Based } \\
\text { Techniques for } \\
\text { Human Activity } \\
\text { Detection }\end{array}$ & CACM & $\begin{array}{l}\text { Proposes using bracelets } \\
\text { with an embedded RFID } \\
\text { tag to detect human } \\
\text { activity }\end{array}$ & $\begin{array}{c}\text { Future } \\
\text { Applications }\end{array}$ \\
\hline 15 & Hsi, Fait & 2005 & $\begin{array}{l}\text { RFID Enhances } \\
\text { Visitors' Museum } \\
\text { Experience at the } \\
\text { Exploratorium }\end{array}$ & CACM & $\begin{array}{l}\text { Described how the } \\
\text { Exploratorium museum in } \\
\text { San-Francisco uses RFID } \\
\text { to create interactive } \\
\text { exhibits }\end{array}$ & $\begin{array}{c}\text { Future } \\
\text { Applications }\end{array}$ \\
\hline 16 & $\begin{array}{l}\text { Ohkubo, Suzuki, } \\
\text { Kinoshita }\end{array}$ & 2005 & $\begin{array}{l}\text { RFID } \\
\text { Privacy/Security } \\
\text { Issues and } \\
\text { Technical } \\
\text { Challenges } \\
\end{array}$ & CACM & $\begin{array}{l}\text { Discusses } \\
\text { Privacy/Security and } \\
\text { security issues related to } \\
\text { RFID }\end{array}$ & Privacy/Security \\
\hline 17 & $\begin{array}{l}\text { Gunther, } \\
\text { Spieakerman }\end{array}$ & 2005 & $\begin{array}{l}\text { RFID and the } \\
\text { Perception of } \\
\text { Control: The } \\
\text { Consumer's View }\end{array}$ & CACM & $\begin{array}{l}\text { Argues that many } \\
\text { consumers will powerless } \\
\text { with respect to the } \\
\text { emerging RFID network. } \\
\text { In order to cope with } \\
\text { consumers' } \\
\text { Privacy/Security fears, } \\
\text { companies need to create } \\
\text { among consumers a } \\
\text { sense of control over their } \\
\text { private information }\end{array}$ & Privacy/Security \\
\hline 18 & $\begin{array}{l}\text { Shim, Arshney, } \\
\text { Dekleva }\end{array}$ & 2006 & $\begin{array}{l}\text { Wireless } \\
\text { Evolution 2006: } \\
\text { Cellular TV, } \\
\text { Wearable } \\
\text { Computing, and } \\
\text { RFID }\end{array}$ & CAIS & $\begin{array}{l}\text { Provides overview of } \\
\text { RFID, lists possible } \\
\text { applications, discusses } \\
\text { Privacy/Security } \\
\text { implications }\end{array}$ & Supply Chain \\
\hline 19 & Sharma, Citurs & 2005 & $\begin{array}{l}\text { Radio Frequency } \\
\text { Identification } \\
\text { (RFID) Adoption } \\
\text { Drivers: A Radical } \\
\text { Innovation } \\
\text { Adoption } \\
\text { Perspective }\end{array}$ & AMCIS & $\begin{array}{l}\text { Investigates antecedents } \\
\text { of an organizational intent } \\
\text { to adopt RFID }\end{array}$ & Supply Chain \\
\hline 20 & Stanton & 2006 & $\begin{array}{l}\text { Consumer Beliefs } \\
\text { about Radio } \\
\text { Frequency }\end{array}$ & AMCIS & $\begin{array}{l}\text { Investigates } \\
\text { Privacy/Security concerns } \\
\text { of the general public in the }\end{array}$ & Privacy/Security \\
\hline
\end{tabular}




\begin{tabular}{|c|c|c|c|c|c|c|}
\hline & & & $\begin{array}{l}\text { Identification } \\
\text { (RFID) Systems }\end{array}$ & & U.S. in relation to RFID & \\
\hline 21 & $\begin{array}{l}\text { Stahl, } \\
\text { Fredenchuss }\end{array}$ & 2006 & $\begin{array}{l}\text { Mobile Business } \\
\text { Through RFID } \\
\text { Technology: } \\
\text { About The } \\
\text { Potential Of RFID } \\
\text { Technology For } \\
\text { Distributing Free } \\
\text { And Paid Content } \\
\text { On Mobile } \\
\text { Devices In Retail } \\
\text { Business }\end{array}$ & AMCIS & $\begin{array}{l}\text { The article focuses on the } \\
\text { convergence of RFID and } \\
\text { mobile technologies and } \\
\text { discusses retail } \\
\text { applications which this } \\
\text { convergence can create }\end{array}$ & Supply Chain \\
\hline 22 & $\begin{array}{l}\text { Wamba, } \\
\text { Bendavid, } \\
\text { Lefebvre, } \\
\text { Lefebvre }\end{array}$ & 2006 & $\begin{array}{l}\text { RFID and the } \\
\text { EPC Network as } \\
\text { Enablers of } \\
\text { Mobile Business: } \\
\text { A Case Study in } \\
\text { the Retail Industry }\end{array}$ & AMCIS & $\begin{array}{l}\text { Investigates how RFID } \\
\text { can potentially impact } \\
\text { various processes in retail }\end{array}$ & Supply Chain \\
\hline 23 & $\begin{array}{l}\text { Knebel, } \\
\text { Leimeister, } \\
\text { Krcmar }\end{array}$ & 2006 & $\begin{array}{l}\text { Strategic } \\
\text { Importance of } \\
\text { RFID - The CIO } \\
\text { Perspective An } \\
\text { Empirical Analysis } \\
\text { in Germany }\end{array}$ & AMCIS & $\begin{array}{l}\text { Investigates the nature of } \\
\mathrm{CIO} \text { perspective in relation } \\
\text { to strategic importance of } \\
\text { RFID in Germany }\end{array}$ & Supply Chain \\
\hline 24 & $\begin{array}{l}\text { Loebbecke, } \\
\text { Palmer }\end{array}$ & 2006 & $\begin{array}{l}\text { RFID Becomes } \\
\text { Fashionable in } \\
\text { the Supply Chain: } \\
\text { The Case of } \\
\text { Kaufhof and Gerry } \\
\text { Weber }\end{array}$ & AMCIS & $\begin{array}{l}\text { Discusses five issues } \\
\text { which have to be } \\
\text { considered in an RFID } \\
\text { implementation project: } \\
\text { physics, process, price, } \\
\text { Privacy/Security, } \\
\text { performance }\end{array}$ & Supply Chain \\
\hline 25 & Angell, Kietzmann & 2006 & $\begin{array}{l}\text { RFID and the End } \\
\text { of Cash? }\end{array}$ & CACM & $\begin{array}{l}\text { Discusses the possibility } \\
\text { of using RFID tags to } \\
\text { track banknotes }\end{array}$ & $\begin{array}{c}\text { Future } \\
\text { Applications }\end{array}$ \\
\hline 26 & $\begin{array}{l}\text { Neumann, } \\
\text { Weinstein }\end{array}$ & 2006 & Risks of RFID & CACM & $\begin{array}{l}\text { Discusses security and } \\
\text { Privacy/Security problems } \\
\text { related to RFID }\end{array}$ & Privacy/Security \\
\hline 27 & $\begin{array}{l}\text { Loebbecke, } \\
\text { Palmer }\end{array}$ & 2006 & $\begin{array}{l}\text { RFID in the } \\
\text { fashion industry: } \\
\text { Kaufhof } \\
\text { department stores } \\
\text { AG and Gerry } \\
\text { Weber } \\
\text { International AG, } \\
\text { fashion } \\
\text { manufacturer }\end{array}$ & $\begin{array}{c}\text { MISQ } \\
\text { Executive }\end{array}$ & $\begin{array}{l}\text { Discusses lessons } \\
\text { learned from a case of } \\
\text { RFID implementation in } \\
\text { retail }\end{array}$ & Supply Chain \\
\hline 28 & $\begin{array}{l}\text { Loebbecke, } \\
\text { Huyskens }\end{array}$ & 2006 & $\begin{array}{l}\text { Weaving the RFID } \\
\text { Yarn at the } \\
\text { Fashion Industry: } \\
\text { The Kaufhof Case }\end{array}$ & $\begin{array}{c}\text { MISQ } \\
\text { Executive }\end{array}$ & $\begin{array}{l}\text { Discusses factors which } \\
\text { led to a successful RFID } \\
\text { implementation in retail; }\end{array}$ & Supply Chain \\
\hline 29 & $\begin{array}{l}\text { Bendoly, Citurs, } \\
\text { Konsynski }\end{array}$ & 2007 & $\begin{array}{l}\text { Internal } \\
\text { infrastructural } \\
\text { impacts on RFID } \\
\text { perceptions and } \\
\text { commitment: } \\
\text { knowledge, } \\
\text { operational } \\
\text { procedures, and } \\
\text { information- } \\
\text { processing } \\
\text { standards }\end{array}$ & $\begin{array}{l}\text { Decision } \\
\text { Sciences }\end{array}$ & $\begin{array}{l}\text { Investigates antecedents } \\
\text { of RFID adoption }\end{array}$ & Supply Chain \\
\hline 30 & $\begin{array}{l}\text { Fedorowicz, } \\
\text { Gogan, Williams }\end{array}$ & 2007 & $\begin{array}{l}\text { RFID and } \\
\text { interorganizational } \\
\text { collaboration: } \\
\text { political and } \\
\text { administrative } \\
\end{array}$ & AMCIS & $\begin{array}{l}\text { Discusses challenges to } \\
\text { RFID adoption for } \\
\text { livestock tracking }\end{array}$ & Supply Chain \\
\hline
\end{tabular}




\begin{tabular}{|c|c|c|c|c|c|c|}
\hline & & & challenges & & & \\
\hline 31 & Golding, Tennant & 2007 & $\begin{array}{l}\text { Performance } \\
\text { metrics: } \\
\text { Evaluating radio } \\
\text { frequency } \\
\text { identification } \\
\text { (RFID) library } \\
\text { system }\end{array}$ & ICIS & $\begin{array}{l}\text { Proposes and approach } \\
\text { for evaluating RFID-based } \\
\text { library systems }\end{array}$ & Supply Chain \\
\hline 32 & $\begin{array}{l}\text { Jensen, Cazier } \\
\text { Dinesh }\end{array}$ & 2007 & $\begin{array}{l}\text { The impact of } \\
\text { government trust } \\
\text { perception on } \\
\text { Privacy/Security } \\
\text { risk perceptions } \\
\text { and consumer } \\
\text { acceptance of } \\
\text { residual RFID } \\
\text { technologies }\end{array}$ & AMCIS & $\begin{array}{l}\text { Investigates antecedents } \\
\text { of consumer risk } \\
\text { perceptions and } \\
\text { acceptance }\end{array}$ & Privacy/Security \\
\hline 33 & $\begin{array}{l}\text { Loebbecke, } \\
\text { Fujita, Huyskens }\end{array}$ & 2007 & $\begin{array}{l}\text { Towards item- } \\
\text { level RFID in the } \\
\text { Japanese } \\
\text { publishing } \\
\text { industry }\end{array}$ & AMCIS & $\begin{array}{l}\text { A case study on item-level } \\
\text { RFID pilot at a Japanese } \\
\text { publishing company }\end{array}$ & Supply Chain \\
\hline 34 & $\begin{array}{l}\text { Niederman, } \\
\text { Mathieu, Morley, } \\
\text { Kwon }\end{array}$ & 2007 & $\begin{array}{l}\text { Examining RFID } \\
\text { application in } \\
\text { supply chain } \\
\text { management }\end{array}$ & CACM & $\begin{array}{l}\text { Discusses managerial, } \\
\text { technological, and } \\
\text { business process level } \\
\text { issues which have to be } \\
\text { addressed when adopting } \\
\text { RFID }\end{array}$ & Supply Chan \\
\hline 35 & $\begin{array}{l}\text { Riemenschneider, } \\
\text { Hardgrave, } \\
\text { Armstrong }\end{array}$ & 2007 & $\begin{array}{l}\text { Is there a } \\
\text { business case for } \\
\text { RFID? }\end{array}$ & AMCIS & $\begin{array}{l}\text { Examines value of using } \\
\text { RFID in the supply chain; } \\
\text { argues that depth of RFID } \\
\text { assimilation is an } \\
\text { antecedent of business } \\
\text { value }\end{array}$ & Supply Chain \\
\hline 36 & Sengupta, Sethi & 2007 & $\begin{array}{l}\text { AMCIS } 2007 \\
\text { panel summary: } \\
\text { The promise of } \\
\text { RFID } \\
\text { technologies }\end{array}$ & CAIS & $\begin{array}{l}\text { Discusses promising } \\
\text { applications of RFID } \\
\text { technology }\end{array}$ & $\begin{array}{c}\text { Future } \\
\text { Applications }\end{array}$ \\
\hline 37 & $\begin{array}{l}\text { Thiesse, Fleisch, } \\
\text { Sorensen }\end{array}$ & 2007 & $\begin{array}{l}\text { RFID-enabled } \\
\text { shelf } \\
\text { replenishment } \\
\text { with case-level } \\
\text { tagging: A } \\
\text { simulation study }\end{array}$ & AMCIS & $\begin{array}{l}\text { A simulation study on how } \\
\text { RFID impacts data quality } \\
\text { and product availability }\end{array}$ & Supply Chain \\
\hline 38 & $\begin{array}{l}\text { Thiesse, } \\
\text { Floerkemeier, } \\
\text { Fleisch, Sorensen }\end{array}$ & 2007 & $\begin{array}{l}\text { Assessing the } \\
\text { impact of } \\
\text { Privacy/Security- } \\
\text { enhancing } \\
\text { technologies for } \\
\text { RFID in the retail } \\
\text { industry }\end{array}$ & AMCIS & $\begin{array}{l}\text { Provides a critical review } \\
\text { of the undesired side- } \\
\text { effects of RFID } \\
\text { Privacy/Security } \\
\text { enhancing technologies }\end{array}$ & Privacy/Security \\
\hline 39 & Yu, Lewis, Guo & 2007 & $\begin{array}{l}\text { RFID Application } \\
\text { in the Food } \\
\text { Industry: A Case } \\
\text { Study of Korean } \\
\text { Food Safety } \\
\text { Information } \\
\text { Systems Project }\end{array}$ & AMCIS & $\begin{array}{l}\text { The study investigates } \\
\text { opportunities, challenges, } \\
\text { and prospects of applying } \\
\text { RFID in the food supply } \\
\text { chain management }\end{array}$ & Supply Chain \\
\hline
\end{tabular}

